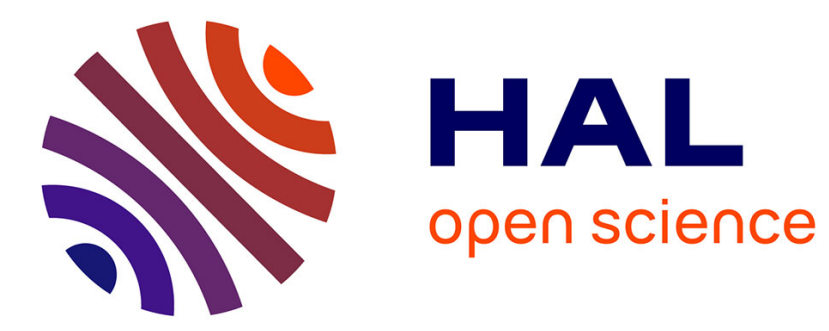

\title{
International Migration and Regional Housing Markets: Evidence from France
}

Hippolyte d'Albis, Dramane Coulibaly, Ekrame Boubtane

\section{To cite this version:}

Hippolyte d'Albis, Dramane Coulibaly, Ekrame Boubtane. International Migration and Regional Housing Markets: Evidence from France. 2017. hal-01469758

\section{HAL Id: hal-01469758 https://hal.science/hal-01469758}

Preprint submitted on 16 Feb 2017

HAL is a multi-disciplinary open access archive for the deposit and dissemination of scientific research documents, whether they are published or not. The documents may come from teaching and research institutions in France or abroad, or from public or private research centers.
L'archive ouverte pluridisciplinaire HAL, est destinée au dépôt et à la diffusion de documents scientifiques de niveau recherche, publiés ou non, émanant des établissements d'enseignement et de recherche français ou étrangers, des laboratoires publics ou privés. 


\section{Z A Institute of Labor Economics}

Initiated by Deutsche Post Foundation

\section{DISCUSSION PAPER SERIES}

IZA DP No. 10516

International Migration and Regional Housing Markets: Evidence from France

Hippolyte d'Albis

Ekrame Boubtane

Dramane Coulibaly 


\section{Z A Institute of Labor Economics}

Initiated by Deutsche Post Foundation

\section{DISCUSSION PAPER SERIES}

IZA DP No. 10516

\section{International Migration and Regional Housing Markets: Evidence from France}

Hippolyte d'Albis

Paris School of Economics, CNRS

\section{Ekrame Boubtane}

CERDI, Universite d'Auvergne,

CES, University Paris 1 and IZA
Dramane Coulibaly

EconomiX-CNRS, University of Paris Ouest

Any opinions expressed in this paper are those of the author(s) and not those of IZA. Research published in this series may include views on policy, but IZA takes no institutional policy positions. The IZA research network is committed to the IZA Guiding Principles of Research Integrity.

The IZA Institute of Labor Economics is an independent economic research institute that conducts research in labor economics and offers evidence-based policy advice on labor market issues. Supported by the Deutsche Post Foundation, IZA runs the world's largest network of economists, whose research aims to provide answers to the global labor market challenges of our time. Our key objective is to build bridges between academic research, policymakers and society.

IZA Discussion Papers often represent preliminary work and are circulated to encourage discussion. Citation of such a paper should account for its provisional character. A revised version may be available directly from the author. 


\section{ABSTRACT}

\section{International Migration and Regional Housing Markets: Evidence from France}

This article examines the causal relations between non-European immigration and the characteristics of the housing market in host regions. We constructed a unique database from administrative records and used it to assess annual migration flows into France's 22 administrative regions from 1990 to 2013. We then estimated various panel VAR models, taking into account GDP per capita and the unemployment rate as the main regional economic indicators. We find that immigration has no significant effect on property prices, but that higher property prices significantly reduce immigration rates. We also find no significant relationship between immigration and social housing supply.

JEL Classification: $\quad$ E20, F22, J61

Keywords: $\quad$ immigration, property prices, social housing, panel VAR

Corresponding author:

Hippolyte d'Albis

Université Paris 1 Panthéon-Sorbonne

106 boulevard de l'Hôpital

75013 Paris

France

E-mail: hdalbis@psemail.eu 


\section{Introduction}

The housing market is a particularly interesting angle for studying immigration in developed countries. It can reveal both the native population's fear of increased difficulty in finding a home, and immigrants' reasons for settling down in a specific locality. Thus, the interactions studied here are similar to those observed in the labor market, but the tensions are potentially greater because the housing market adjusts more slowly. In this paper, we study the relationship between immigration and the housing market at a regional level in France over the period 1990-2013. To our knowledge, this is the first study of its kind for France.

There are four main facts that characterize the relationship between immigration and housing in France. Firstly, the foreign-born population is very unevenly spread around the country. According to census data, the three main French administrative regions : Ile-de-France (the Paris region), Rhône-Alpes and Provence-Alpes-Côte d'Azur, are home to one-third of the native population but two-thirds of the foreign population. Secondly, local housing markets are very mixed in terms of prices: average prices in different regions can differ by as much as $100 \%$. Thirdly, the social housing sector, i.e. rental housing subject to access restrictions and provided at below market prices, is important and represents $44 \%$ of the overall rental housing stock in France. However, this social housing is also unevenly spread around the country; for example, $30 \%$ of all social housing is in the Paris region. Lastly, the native and foreign populations are differently distributed according to occupancy status of the housing unit: $75 \%$ of non-European immigrants live in rented accommodation compared to $34 \%$ of the non-immigrant population. Among tenants, the percentages of native- and foreign-born living in social housing are $40 \%$ and $52 \%$ respectively (see Fougère et al., 2013, for detailed analysis of the statistical association between social housing policy and location choice). These facts illustrate a lack of uniformity both geographically and within the housing market for the immigrant and non-immigrant populations, though it does not necessarily imply sharp segmentation.

The interaction between immigration and local housing markets is theoretically ambiguous. The inflow of immigrants into a region would increase the demand of housing in that region. The effect on prices depends on the supply and demand adjustments. In the basic stock-flow model of the housing sector, housing prices adjust to equalize the changes in demand in the shortrun given the already existing stock of housing (supply) (See Di Pasquale and Wheaton (1994), for a review.) However, the supply of housing itself adjusts to these changes: the stock expands gradually with new building. If housing markets are not regulated, housing prices are expected to positively react 
to an inflow of immigrants in the short run, while the long run effect would depend on the responsiveness of housing supply to changes in market conditions. In practice, housing markets are often regulated and the adjustment of prices could be constrained, therefore delaying supply adjustment. An additional difficulty lies on the fact that housing conditions could influence the choice of location for immigrants. All else equal, particularly economic conditions, immigrants may choose to settle in a region where housing is more affordable in the first place.

Our aim is to establish causal links between the variables that characterize immigration and those that characterize the housing market. As highlighted above, the endogeneity is obvious here: migration flows may create tensions on local markets, which may push prices upwards; and the same time local market conditions may affect the size of the flow by influencing immigrants' choice of locality. In examining the influence of international migration on host economic conditions, different approach was considered to address this endogeniety interaction. The first approach consists to rely on natural experiment. ${ }^{1}$ The second approach uses instrumental variable approach. Due to persistence in migration flow, one can rely on internal instruments, i.e., lagged values as instruments (for example, as in Dustmann et al., 2005). A recent method inspired from trade literature, uses external instruments obtained for gravity model prediction, particularly on in cross-sectional data (such in Alesina et al., 2016; Ortega and Peri, 2014). In our case, there is no recent natural experiment and a gravity-based approach on international migration would be difficult to implement at the regional level of host country. We therefore deal with the endogeneity by using a vector autoregressive (VAR) approach that brings out the persistence behind the use of lagged values as instruments in the single equation approach. In lack of satisfactory external instruments, the VAR approach has been designed to addresses the endogeneity issue by allowing a dynamic interaction between variables in the system (Sims, 1980). VAR models have thus the advantage to analyze the effects of a shock impacting one variable on other variables of interest, over time. As explained above, this dynamic analysis becomes a very useful tool. Following Blanchard and Katz (1992)'s ground-breaking article, this method has been used convincingly to asses regional performance. In particular, Zabel (2012) studies the causal links between migration and housing in US metropolitan statistical areas (MSAs). In short, with an appropriate identification in the VAR, we are able to examine the dynamic impact of an exogenous migration shock (i.e. not caused by host economic conditions) on

\footnotetext{
${ }^{1}$ This strategy was used by Hunt (1992) and Verdugo (2016) to study immigration in the 1960 s and the 1970 s.
} 
French regional housing and economic variables, and vice versa.

The main difficulty for studying this issue in France is that of data availability. In particular, there were no region-by-region statistical series on international migration flows covering a sufficiently long period. As such, we had to build an original database from the administrative information system of France's local police authorities (préfectures), which has recorded all residence permits issued to foreigners. Since nationals of European Economic Area and Switzerland no longer need a residence permit to settle in France, this database does not contain reliable information on European-immigrants after the entry into force of the freedom of movement in Europe. Thus, we focus on legal immigration of third-country nationals (non-EU migrants) which are subject to French immigration policy. The migration flows of non-European nationals are consequently produced on the basis of residence permit statistics collected at regional levels from 1990 to 2013.

We estimated two panel VAR models. The first includes migration flows, property prices and two variables for the regions' economic situation (GDP per capita and the unemployment rate). The second model also adds social housing supply. The impulse response functions from the first model show that a property price increase does cause a reduction in immigration flows and, conversely, that an increase in migration flows does not cause a property price increase. Our first result is due to the particular characteristics of immigration in France, which is mostly family immigration. Tensions in the property market make this kind of immigration more difficult. We have illustrated this by breaking down the migration flows by the person's sex or country of origin. Our second result, which goes against the theoretical intuition, could be explained by the segmentation of the housing market. However, the impulse response functions show that our results do not change when taking into account interregional differences in the social housing supply. In addition, we show that a more abundant supply of social housing does not cause an increase in immigration. This result also highlights the changes in the nature of immigration and in attitudes towards it in France. Verdugo (2016) showed that a 'social housing magnet effect' was apparent in the late 1970s, when there was still much immigration for work purposes. Our results suggest this is not the case anymore.

The remainder of this article is structured as follows: Section 2 describes the data and more specifically our immigration database; Section 3 presents the econometric methodology; Section 4 details the empirical results and compares them to relevant findings in the literature; finally Section 5 concludes. 


\section{Data Description}

Our database covers the 22 administrative regions of Metropolitan France, i.e. excluding the French overseas territories, annually over the period 1990-2013. The regional level is "NUTS 2" that follows the European Union's definition of regional units. The choice of the geographic unit was constrained by the availability of housing data at the local level for France. Nevertheless, more than an administrative division, each region has some degree of political and economic autonomy. Our first contribution was to set up a region-byregion database on international migration, the housing market and economic performances. This is a new and original database on international migration flows to French regions.

In France, the principal sources of migration data are population censuses and the residence permits database. Although French decennial population censuses organized by the French National Institute of Statistics and Economic Studies (INSEE) provide a rich dataset on migration stock for census years, we require annual data on immigration for the purposes of this research. An additional source of information is the residence permits database available at the national level from the French Institute for Demographic Studies (INED) since 1994 and from EUROSTAT since 2008. This source of data has recorded all foreigners for whom a residence permit is required in order to settle in France. So, the residence permits database does not contain reliable information on nationals of European Economic Area and Switzerland, as they no longer need a residence permit to settle in France. Note that these data do not contain either information on foreigners' departures. Foreign outflows are generally unregulated and pose more measurement problems than legal inflows. Still, the residence permit database is the best available data for France to provide annual harmonized and comparable data on international migration flows.

Consequently, we take advantage of the automatic data collection of residence permits to built regional gross migration flows of non European nationals. $^{2}$ More precisely, regional immigration flows were constructed from the central foreigners register, managed by the Ministry of the Interior, that is more specifically called Application de Gestion des Dossiers de Ressortissants Etrangers (AGDREF) (i.e the application for managing files of foreign nationals in France), which records all residence permits issued in the country. Data are provided by the statistical service of the Ministry -Département des Statistiques, des Etudes et de la Documentation (DSED)- to the INED.

\footnotetext{
${ }^{2}$ More precisely, we exclude nationals from EU-27 countries and from Andorra, Iceland, Liechtenstein, Monaco, Norway, San Marin, Switzerland and Vatican for the sample period.
} 
Computerized records of residence permits began in France in 1982. The AGDREF register was created in 1993 to put together the data on residence permits with all other administrative details on permit holders. A more extensive description of AGDREF and its methodology is explained in d'Albis and Boubtane (2015). We use the AGDREF information on the département (NUTS 3) to point out where the residence permit was issued and at which date the immigrant entered into France to build a regional-level dataset on immigration by sex and nationality. It is, however, not possible to decompose the flows by reasons of issue of the residence permit as this information is not available in AGDREF for the early 1990s. The migration flows take into account all adults (aged 18 or over) who received a residence permit valid for one year or more, for the first time, over the period. We consider all legal immigrants in France including irregular immigrants who have been regularized. These later ones are counted when they arrive in France rather than when their status changed, since we use the immigrant's date of entry to compute flows. This series of regional migration flows is, to our knowledge, the first to be produced for France. We used it to calculate regional immigration rates, i.e. the ratio between the annual regional migration flow and the number of persons of working-age in the region at the midpoint of the year.

Despite its importance, we know surprisingly little about the evolution of the French regional housing market over the last decades. Local data are scarce and most available data are related to a limited number of regions over a recent period of time. It was not until 1983 that the INSEE calculated a price index for the existing property in Paris city. The series was based on transactions registered in Paris notarial offices. In order to cover the rest of France, two agreements have been signed in 1998 and 1999 between INSEE and the Higher Notary Council (Conseil Supérieur du Notariat) to produce local housing price indexes for the whole French territory (see David et al. (2002)). Henceforth, the Notary-INSEE housing price index is published for three regions (Ile de France, Provence-Alpes-Côte d'Azur and Rhône-Alpes) since 1996 and for Nord-Pas-de-Calais since 2007. It should be noted that the data on transactions from the notary database is the main source used by housing market analysts in France. However, the geographic and temporal coverage of these data is very limited. Precisely, transactions data of Paris notarial offices (Base d'Informations Economiques Notariales - BIEN) cover all the departments of Ile-de-France (the Paris region) since 1996 only. The data coverage of the Higher Notary Council database (PREVAL) is even more reduced especially in the 1990s. Clarenc et al. (2014) estimate that the notary database covered only $56 \%$ for the provincial France in 2010. Moreover, the collection and transmission of transaction data by notarial offices is 
voluntary and data gathering is not part of the public service mission of the notary until 2011. An alternative source of information on regional housing prices in France is new property prices produced by the statistical department -Service de l'Observation et des Statistiques (SOeS)- of the French Ministry of the Environment, Energy and Marine Affairs (MEEM). Data came from a survey on the sale of new homes, the Enquête sur la Commercialisation des Logements Neufs (ECLN) which is a part of the annual program of public service statistical surveys. Responding to the ECLN is mandatory and property management companies have to pay an administrative fine if they do not respond or if they transmit inaccurate information. SOeS publish data on new propriety prices at both the NUTS 2 regional level and the national level (Eider database (2015)). To the best of our knowledge, there is no other regional indicator for real estate prices in France that cover the period 1990-2013. Below, we use the average sale prices (in euros per square meter) of apartments in newly-constructed buildings as a proxy for housing prices at regional levels. We checked that the newly-built homes series were strongly correlated with the Notary-INSEE housing prices index in the three regions for which data are available since 1996. It should be noted that data on rents are provided by INSEE as a part of the consumer price index from national accounts, but at the national level only. Finally, real house prices are given by the ratio of nominal housing price (from Eider database (2015)) to the consumers expenditure deflator, from the INSEE national accounts database.

The statistical department of the MEEM also publish data on the social rental housing stock, i.e. all units of social housing providers (bailleurs sociaux et sociétés d'économie mixte), which are nonprofit organizations that provide housing at affordable rents (HLM - habitation à loyer modéré). In France, social housing is allocated to eligible tenants through local administrative procedures. There is a queuing system in each department with consideration given to some priority-rated households (particularly the vulnerable households who have waited long for a social housing). Social housing stock data are based on two surveys, le répertoire du parc locatif des bailleurs sociaux (RPLS) until 2010 then l'enquête sur le parc locatif social (EPLS). The survey is conducted annually among social housing providers and their participation is mandatory. Data are available at the NUTS 2 level from Eider database (2015) and annual publications of SOeS in its collection "Chiffres \& Statistiques". The stock of social housing adjusts through new construction, sales ${ }^{3}$ or demolitions. What we name below the social housing

\footnotetext{
${ }^{3}$ In France, tenants of social housing have, since 1965, the possibility to buy their dwelling at a discounted price, below market value. Sold units of social housing represented
} 
supply is annual variation of the stock, rather than the stock itself, following standard practice in the literature on housing markets. Moreover, this variable is a good indicator of regional social housing dynamics ${ }^{4}$. Note that our statistics are not the same as those used by Verdugo (2016), who obtained the information from the population censuses of 1982, 1990 and 1999. We wanted annual time series, which the censuses would not have allowed.

Regional economic data are produced by the INSEE. We use the real regional GDP (chain-linked volume with 2010 as a reference year) and divided it by the size of the working-age population at the midpoint the year. For simplicity, we refer to this variable as "GDP per capita". Regional unemployment rate are computed as the annual average of the quarterly estimates of the proportion of the labor force who are seeking employment.

Table 1: Descriptive statistics

\begin{tabular}{|c|c|c|c|c|c|}
\hline Region & $\begin{array}{c}\text { Mig. } \\
\text { rate } \\
(\text { per } 1,000)\end{array}$ & $\begin{array}{c}\text { real GDP } \\
\text { per capita } \\
\text { (base 2010) }\end{array}$ & $\begin{array}{c}\text { Unemp. } \\
\text { rate } \\
\text { (in \%) }\end{array}$ & $\begin{array}{c}\text { real hous. } \\
\text { price } / m^{2} \\
\text { (base } 2010 \text { ) }\end{array}$ & $\begin{array}{c}\text { Soc. hous. } \\
\text { supply } \\
\text { (per } 1,000)\end{array}$ \\
\hline Alsace & 3.08 & 42052 & 6.59 & 2275 & 0.95 \\
\hline Aquitaine & 1.75 & 39961 & 8.80 & 2506 & 1.13 \\
\hline Auvergne & 1.57 & 37289 & 8.06 & 2180 & 1.10 \\
\hline Basse-Normandie & 1.14 & 37721 & 8.34 & 2620 & 0.82 \\
\hline Bourgogne & 1.53 & 39542 & 7.99 & 2190 & 0.72 \\
\hline Bretagne & 1.25 & 38439 & 7.59 & 2327 & 1.30 \\
\hline Centre & 1.93 & 39982 & 7.74 & 2344 & 0.92 \\
\hline Champagne-Ardenne & 1.68 & 40369 & 9.16 & 2279 & 0.81 \\
\hline Corse & 2.96 & 34507 & 10.29 & 2375 & 0.84 \\
\hline Franche-Comté & 2.19 & 37149 & 7.54 & 2081 & 0.56 \\
\hline Haute-Normandie & 1.80 & 39706 & 9.99 & 2392 & 1.12 \\
\hline Ile-de-France (Paris region) & 6.63 & 66133 & 7.92 & 3813 & 1.49 \\
\hline Languedoc-Roussillon & 2.87 & 35059 & 12.47 & 2490 & 1.52 \\
\hline Limousin & 1.67 & 36895 & 7.27 & 2090 & 0.74 \\
\hline Lorraine & 1.88 & 35678 & 8.43 & 2032 & 0.52 \\
\hline Midi-Pyrénées & 2.30 & 39463 & 8.65 & 2436 & 1.27 \\
\hline Nord-Pas-de-Calais & 1.62 & 35312 & 12.03 & 2434 & 1.36 \\
\hline Pays de la Loire & 1.43 & 39951 & 7.88 & 2498 & 1.09 \\
\hline Picardie & 1.68 & 35861 & 9.76 & 2381 & 1.09 \\
\hline Poitou-Charentes & 1.32 & 37442 & 8.62 & 2473 & 0.78 \\
\hline Provence-Alpes-Côte d'Azur & 3.32 & 42134 & 11.03 & 3344 & 0.94 \\
\hline Rhône-Alpes & 2.98 & 44339 & 7.94 & 2680 & 1.41 \\
\hline France Metropolitan & 2.21 & 39772 & 8.82 & 2465 & 1.02 \\
\hline
\end{tabular}

Table 1 shows the mean values of variables considered over the period 1990-2013. It can be easily noted that the Paris region is the one where real GDP per capita, migration rate (migration as a share of working-age

$0.3 \%$ of the aggregate social housing stock in 2013 .

${ }^{4}$ It should be noted that subsidized dwellings are of uniform size regardless of region or year: the average number of rooms is around three per housing unit 
Figure 1: Migration rate and housing price
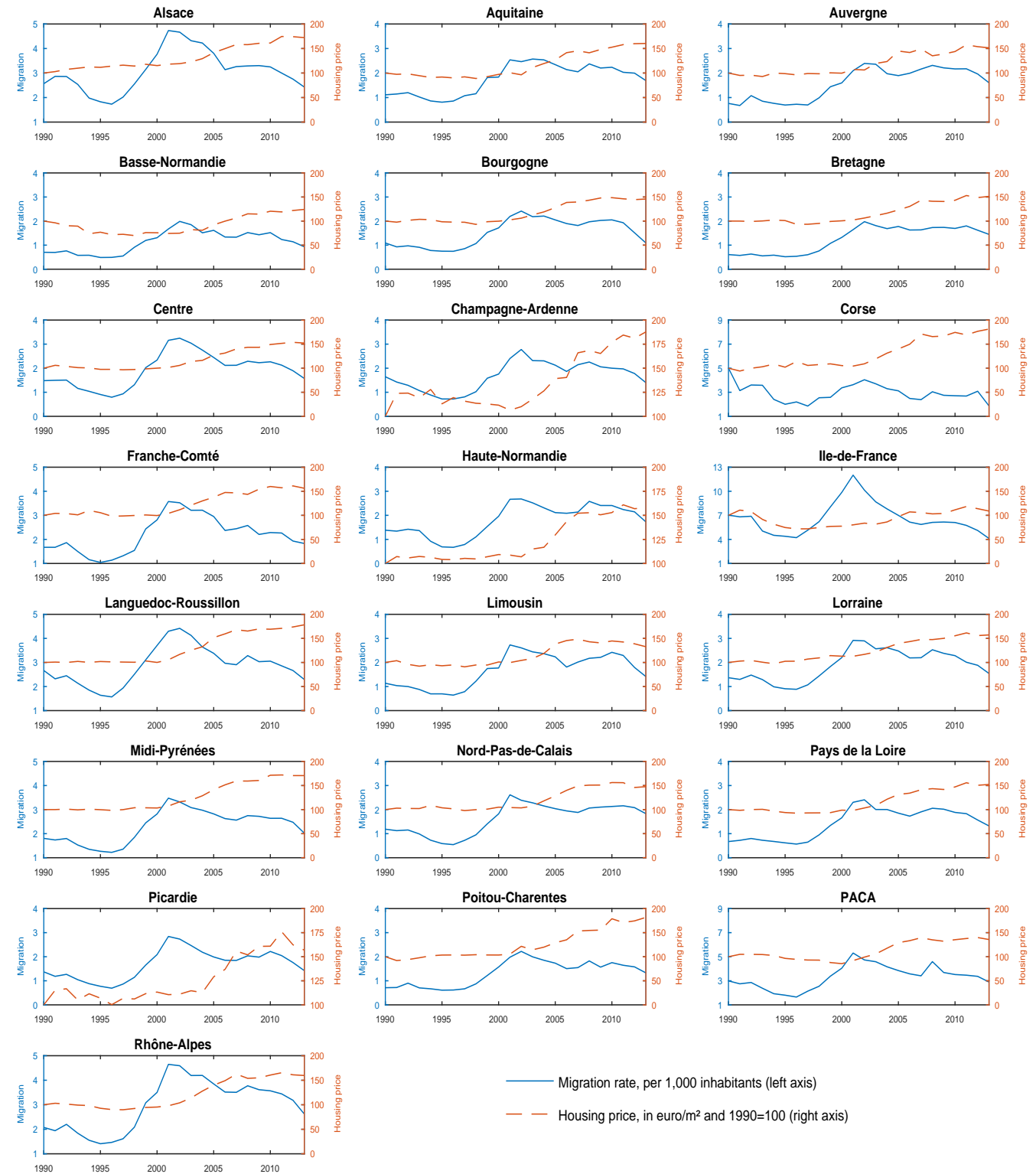

- Migration rate, per 1,000 inhabitants (left axis)

- Housing price, in euro/ $\mathrm{m}^{2}$ and $1990=100$ (right axis)

Source: Authors' computations based on data from INED (AGDREF/DSED) and SOeS. 
Figure 2: Migration rate and social housing supply
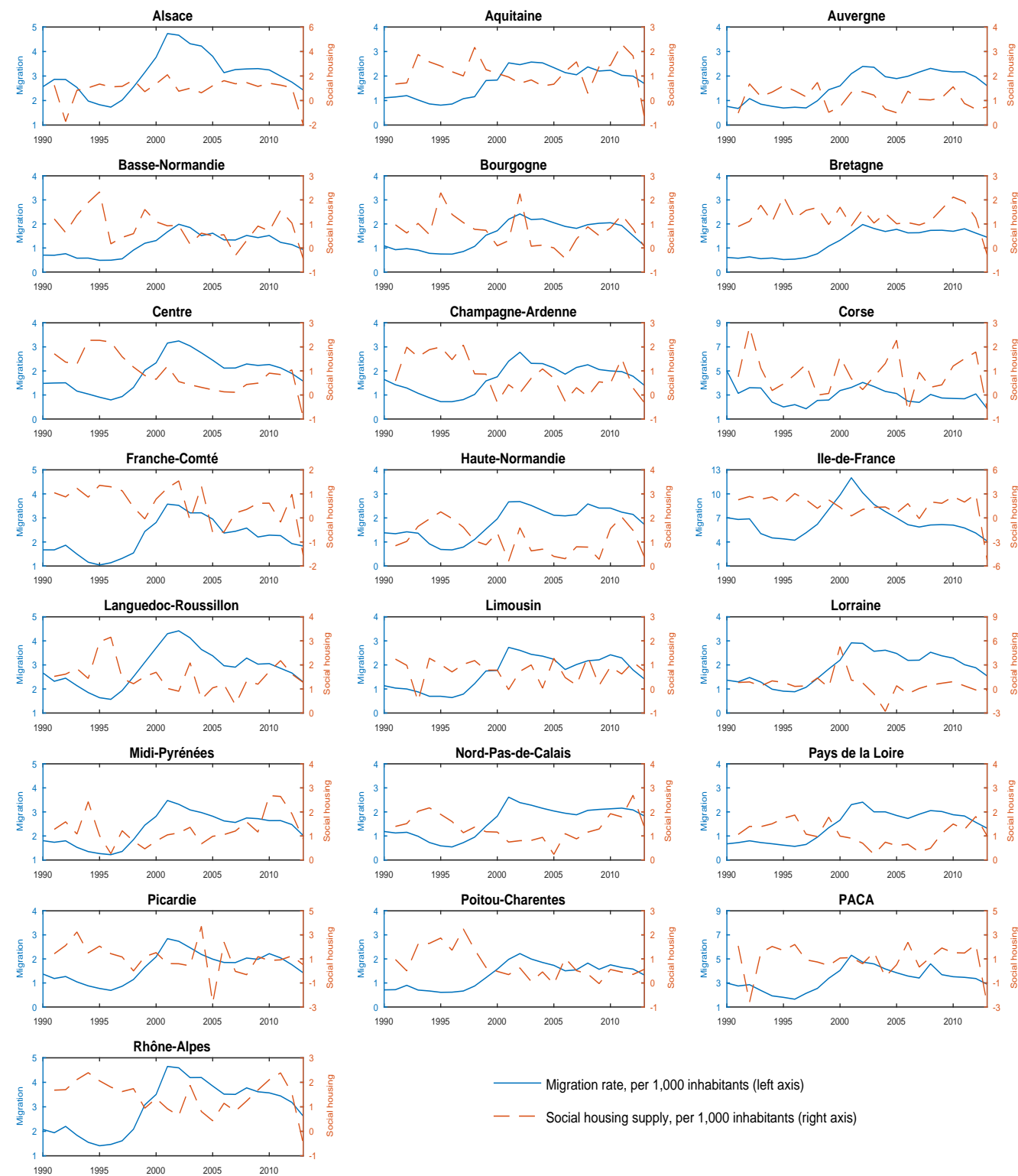

Migration rate, per 1,000 inhabitants (left axis)

_ - Social housing supply, per 1,000 inhabitants (right axis)

Source: Authors' computations based on data from INED (AGDREF/DSED) and SOeS. 
Figure 3: Migration rate and real GDP per capita
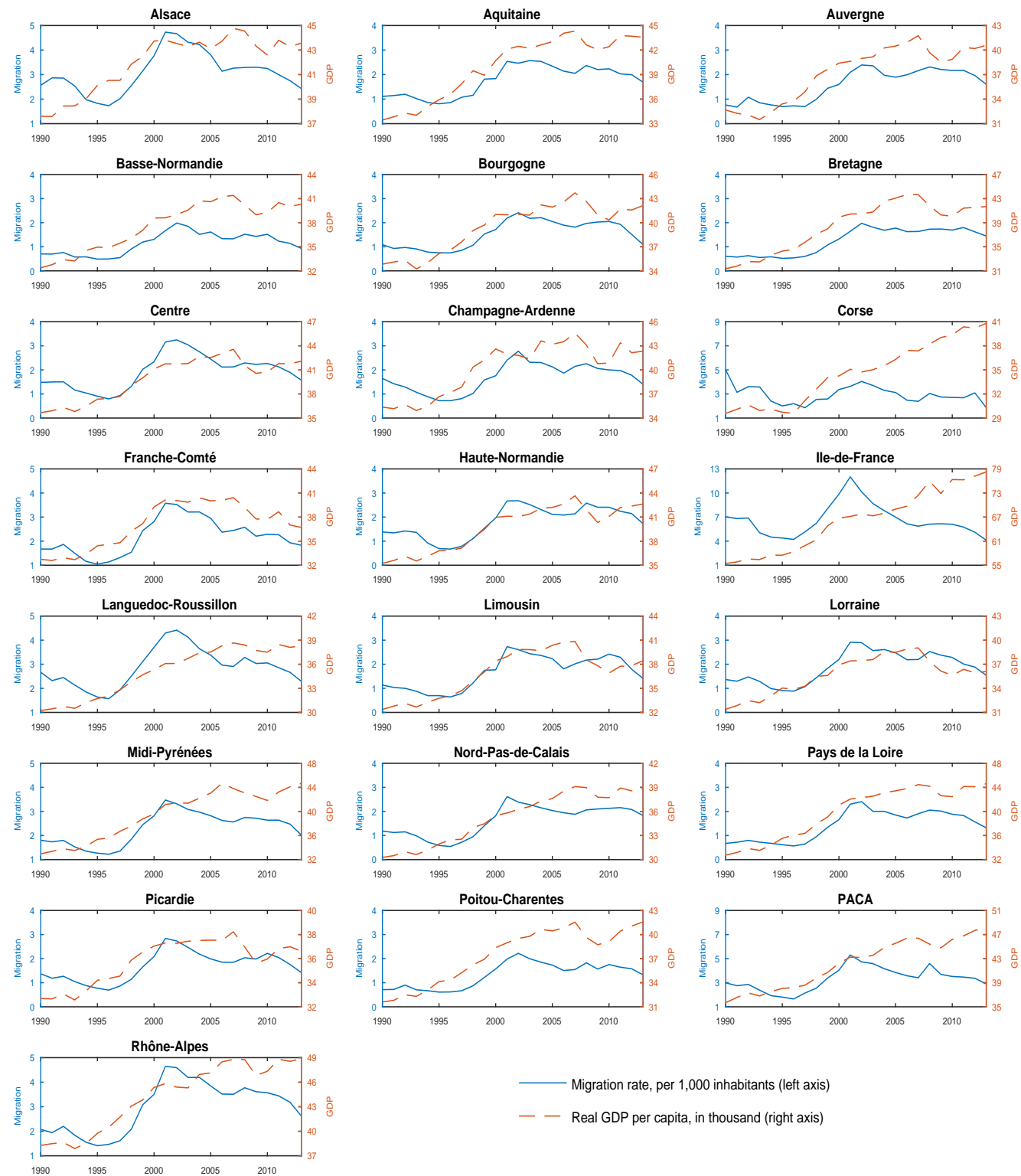

- - Real GDP per capita, in thousand (right axis)

Source: Authors' computations based on data from INSEE and INED (AGDREF/DSED). 
Figure 4: Migration rate and unemployment rate
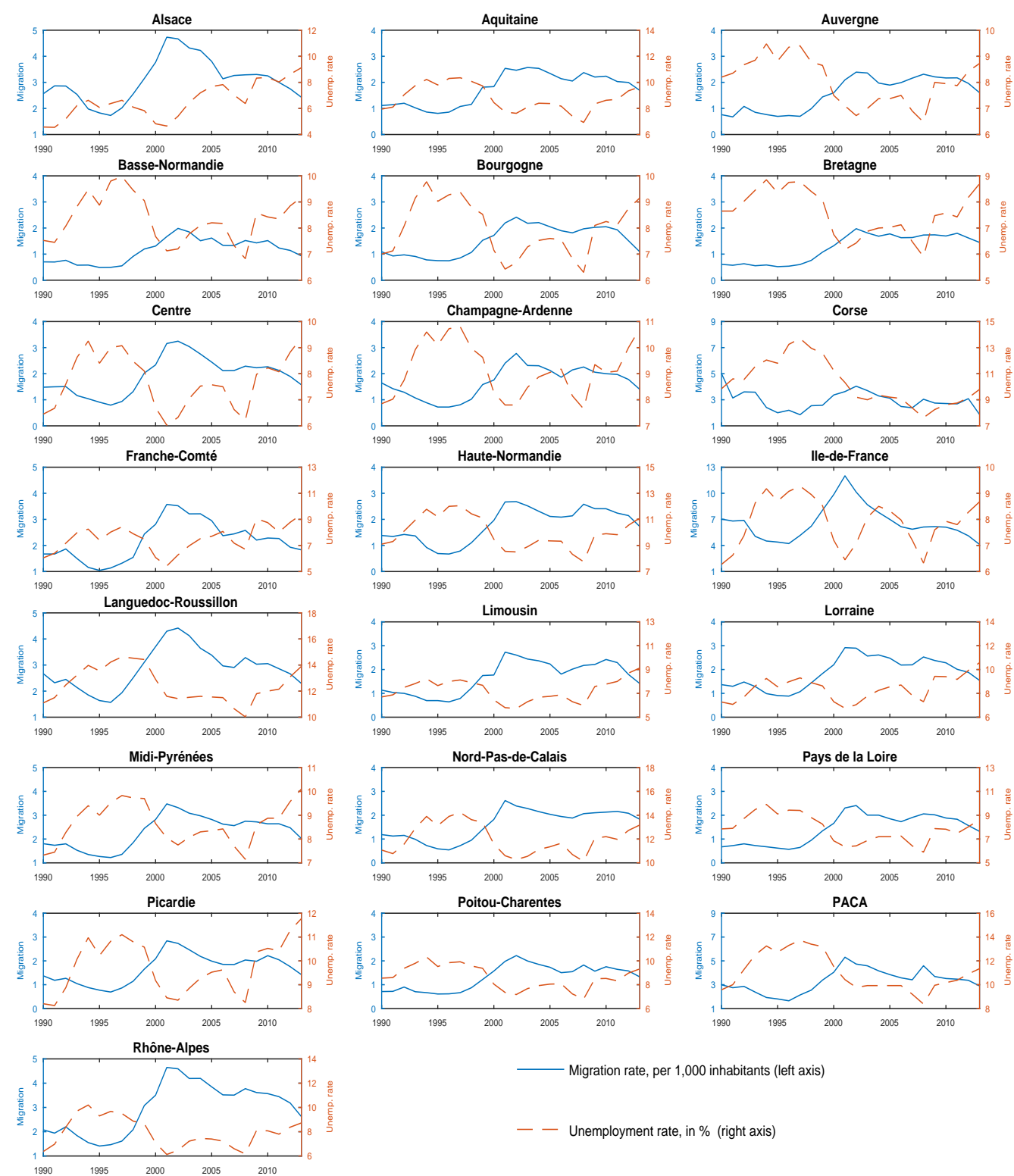

Migration rate, per 1,000 inhabitants (left axis)

- - Unemployment rate, in \% (right axis)

Source: Authors' computations based on data from INSEE and INED (AGDREF/DSED). 
Figure 5: The relationship between migration and housing price (upper panel) and social housing supply (lower panel)

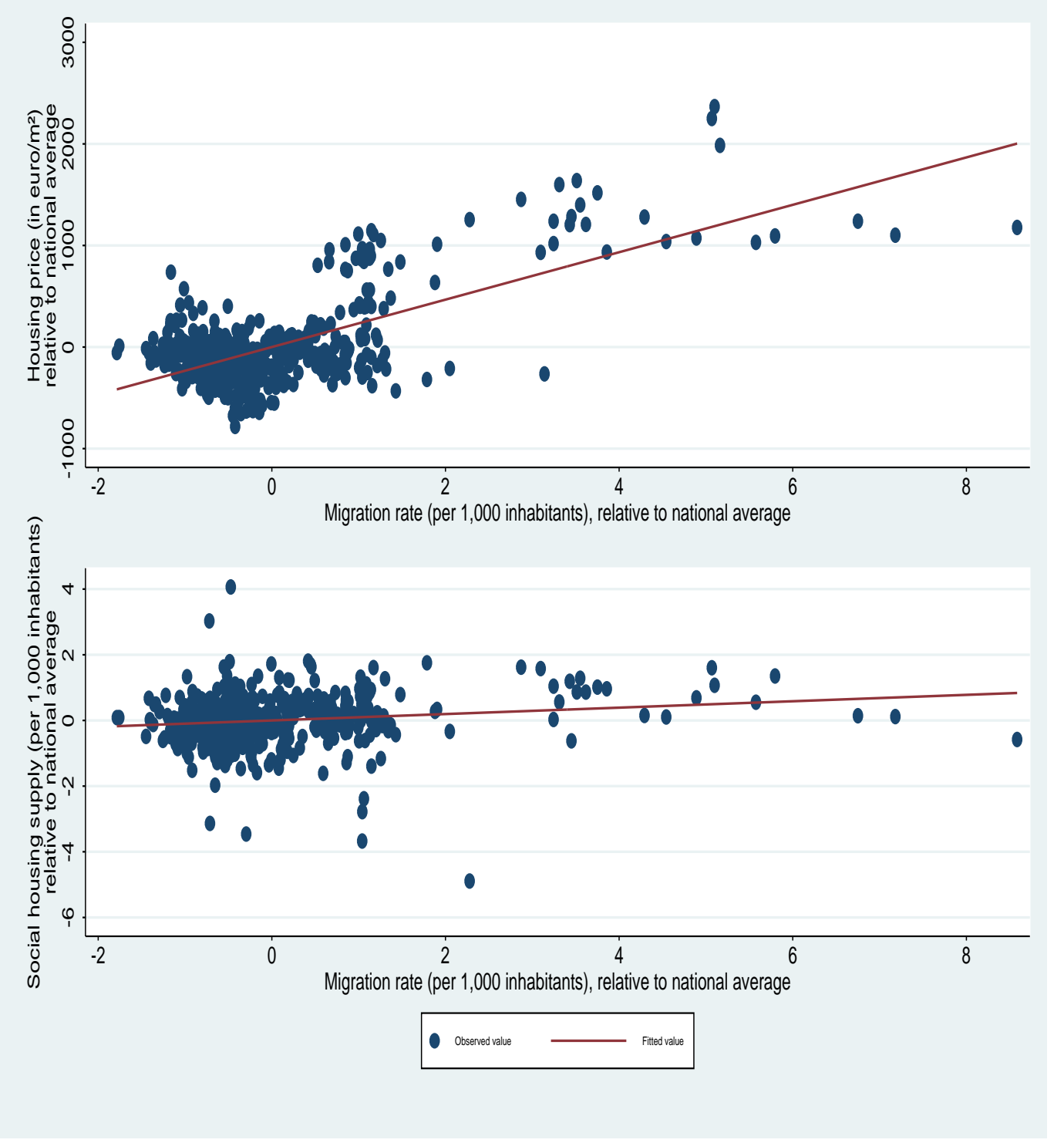

Source: Authors' computations based on data from INED (AGDREF/DSED) and SOeS. 
population at the midpoint the year) and housing price are the highest, while the Languedoc-Roussillon region has the highest social housing supply per working-age population at the midpoint the year (1.52 per 1,000 inhabitants on average over the 1990-2013 period compared to 1.49 per 1,000 inhabitants in Ile-de-France). Figures 1-4 give the time trends for our variables, each graph showing changes in the immigration rate and one of the other four variables. The pattern varies widely between regions. For example, the effects of the 2008 crisis on both GDP per capita and the unemployment rate differ widely by region. The extent of the property price rise between 2000 and 2008 also varies considerably from one region to another, and a convergence in prices can be observed. Moreover, it is apparent from Figures 1-4 that all variables display a significant variability over time. In particular, social housing stock per inhabitant grew by $0,8 \%$ on average over the sample period. The raise of social housing stock is significant given that total housing stock increases by $0,6 \%$ over the 1990-2013.

Figure 5 shows the positive local correlations between the immigration rate and property prices, while the correlation between the immigration rate and net social housing supply is almost zero. These correlations remain valid if the data for Ile-de-France are excluded.

\section{Empirical Strategy}

\subsection{Methodological preliminaries}

Our empirical analysis is based on a panel VAR model with the following specification:

$$
Y_{i t}=u_{i}+A_{1} Y_{i t-1}+\ldots+A_{p} Y_{i t-p}+\varepsilon_{i t}, i=1, \ldots, N \text { and } t=1, \ldots, T
$$

where $Y_{i t}=\left(y_{1 t}^{1}, \ldots, y_{i t}^{K}\right)^{\prime}$ is a $(K \times 1)$ vector of endogenous variables, the $A_{j}$ are fixed $(K \times K)$ coefficient matrices, $u_{i}=\left(u_{i}^{1}, \ldots, u_{i}^{K}\right)^{\prime}$ is a fixed $(K \times 1)$ vector of individual effects, and $\varepsilon_{t}=\left(\varepsilon_{i t}^{1}, \ldots, \varepsilon_{i t}^{K}\right)^{\prime}$ is the $(K \times 1)$ vector of residuals satisfying $E\left(\varepsilon_{i t}\right)=0$ and $E\left(\varepsilon_{i t} \varepsilon_{i t}^{\prime}\right)=\Omega . \mathbb{1}\{t=s\} \forall i$ and $t$.

In panel data models with fixed effects, when the number of individuals $(N)$ is large relative to the time series dimension $(T)$, the Least Squares Dummy Variables (LSDV) technique (Ordinary Least Squares (OLS) putting directly individual effects as regressors) would lead to inconsistent estimates of the common parameter of interest, well-known as the incidental parameter problem. To tackle this issue in a static panel model, a usual solution is to use Fixed Effects (Within) estimation technique that estimates the common parameters on a transformed model in which individual effects are eliminated by 
de-meaning the variables (within transformation). According to the FrischWaugh theorem, the within-estimator of common parameters is numerically identical to the LSDV estimator. In a dynamic panel, it is well-known that the fixed effects estimator is not consistent for a finite time dimension $T$ even when the cross-sectional dimension $N$ is large. More precisely, as the fixed effects are correlated with the regressors due to lags of the dependent variables, using the Fixed Effects estimation approach gives a biased estimator. This bias, named as the Nickell bias, is inversely proportional to the time dimension $(T)$ of the panel (Nickell, 1981).

To estimate a dynamic panel model with fixed effects, a first approach is to use instrumental variables (IV) or generalized method of moments (GMM) techniques. This approach based on IV/GMM techniques is designed for the case where $N / T$ is relatively high (see e.g. Love and Zicchino, 2006; Boubtane et al., 2013; Lengyel and Eriksson, 2016, for an example of panel VARs). A second approach employs the fixed effects estimator, since the Nickell bias approaches zero if the time dimension is very large, requiring a sufficiently large time dimension (see e.g. Alesina et al. (2002) and Beetsma et al. (2008), for an example of panel VARs). When $T$ and $N$ are of comparable sizes, i.e. when $0<\lim N / T<\infty$, these first two approaches are less appropriate and a third approach is preferred. This third approach considers a bias-corrected version of the fixed-effects estimator. In the context of the single-equation dynamic panel data models, Kiviet (1995) has proposed bias-corrections to the fixed effects estimator. Hahn and Kuersteiner (2002) has suggested a bias-corrected version of the fixed-effects estimator that is generalized to panel Vector Autoregressions (VAR) models. As argued by Hahn and Kuersteiner (2002), their bias-corrected estimator does not require a preliminary consistent estimator (for example, GMM estimator) and may be understood as an implementable version of Kiviet's estimator. Moreover, Monte Carlo simulations made by Hahn and Kuersteiner (2002) show that the efficiency of bias-corrected estimator measured by the root mean squared error (RMSE) often dominates that of the GMM estimator.

In our study $N=22$ and $T=24$, we therefore use the bias-corrected estimator of Hahn and Kuersteiner (2002). This estimator is given as follows. By imposing blockwise zero and identity restrictions on the VAR slope coefficients, any $V A R(p)$ process can take a $V A R(1)$ form (Hahn and Kuersteiner, 2002; Lütkepohl, 2005, p. 15). Let $y_{i t}=\left(Y_{i t}, Y_{i t-1}, \ldots, Y_{i t-p+1}\right)^{\prime}$, equation (1) can be rewritten as,

$$
y_{i t}^{\prime}=\alpha_{i}^{\prime}+y_{i t-1}^{\prime} \beta^{\prime}+e_{i t}^{\prime}, i=1, \ldots, N \text { and } t=1, \ldots, T
$$


where,

$$
\alpha_{i}=\left[\begin{array}{c}
u_{i} \\
0 \\
0 \\
\vdots \\
0
\end{array}\right], \beta=\left[\begin{array}{ccccc}
A_{1} & A_{2} & \cdots & A_{p-1} & A_{p} \\
I_{K} & 0 & & 0 & 0 \\
0 & I_{K} & & 0 & 0 \\
\vdots & & \ddots & \vdots & \vdots \\
0 & 0 & \cdots & I_{K} & 0
\end{array}\right], e_{i t}=\left[\begin{array}{c}
\varepsilon_{i t} \\
0 \\
0 \\
\vdots \\
0
\end{array}\right]
$$

The within estimator of $\beta$ takes the form of,

$$
\hat{\beta}^{\prime}=\left(\sum_{i=1}^{N} \sum_{t=1}^{T}\left(y_{i t-1}-\bar{y}_{i-}\right)\left(y_{i t-1}-\bar{y}_{i-}\right)^{\prime}\right)^{-1}\left(\sum_{i=1}^{N} \sum_{t=1}^{T}\left(y_{i t-1}-\bar{y}_{i-}\right)\left(y_{i t}-\bar{y}_{i}\right)^{\prime}\right)
$$

where

$$
\bar{y}_{i} \equiv \frac{1}{T} \sum_{t=1}^{T} y_{i t} \text { and } \quad \bar{y}_{i-} \equiv \frac{1}{T} \sum_{t=1}^{T} y_{i t-1} .
$$

Under the condition that $0<\lim N / T=\rho<\infty$, if all the innovations $\varepsilon_{i t}$ are independent for all $i$ and $t$, Hahn and Kuersteiner (2002) show that,

$$
\sqrt{N T} \operatorname{vec}\left(\hat{\beta}^{\prime}-\beta^{\prime}\right) \rightarrow \mathcal{N}\left(-\sqrt{\rho}\left(I_{K} \otimes \Upsilon\right)^{-1}\left(I_{K} \otimes I_{K}-\left(I_{K} \otimes \beta\right)\right)^{-1} \operatorname{vec}(\Omega), \Omega \otimes \Upsilon^{-1}\right)
$$

where vec is the column stacking operator and $\Upsilon=\Omega+\beta \Omega \beta^{\prime}+\beta^{2} \Omega\left(\beta^{\prime}\right)^{2}+\ldots$. The Hahn and Kuersteiner (2002) bias-corrected within estimator $\hat{\hat{\beta}}$ is then given by,

$$
\begin{aligned}
\operatorname{vec}\left(\hat{\hat{\beta}}^{\prime}\right) & \equiv\left[I_{k} \otimes\left(\frac{1}{N T} \sum_{i=1}^{N} \sum_{t=1}^{T}\left(y_{i t-1}-\bar{y}_{i-}\right)\left(y_{i t-1}-\bar{y}_{i-}\right)^{\prime}\right)^{-1}\right] \\
& \times\left[\frac{1}{N T}\left(\sum_{i=1}^{N} \sum_{t=1}^{T}\left(I_{K} \otimes\left(y_{i t-1}-\bar{y}_{i-}\right)\right)\left(y_{i t}-\bar{y}_{i}\right)^{\prime}\right)\right. \\
& \left.+\frac{1}{T}\left[I_{K} \otimes I_{K}-\left(I_{K} \otimes \hat{\beta}\right)\right]^{-1} \operatorname{vec}(\hat{\Omega})\right],
\end{aligned}
$$

where $\hat{\Upsilon}=\frac{1}{N T} \sum_{i=1}^{N} \sum_{t=1}^{T}\left(y_{i t-1}-\bar{y}_{i-}\right)\left(y_{i t-1}-\bar{y}_{i-}\right)^{\prime}$,

and $\operatorname{vec}(\hat{\Omega})=\left[I_{K} \otimes I_{K}-(\hat{\beta} \otimes \hat{\beta})\right] \operatorname{vec}(\hat{\Upsilon})$

\subsection{Estimated models}

We estimated two models separately. The first one is a four-dimensional VAR model in which the vector of endogenous variables $Y_{i t}$ is:

$$
\text { Model } 1 Y_{i t}=\left(M_{i t}, H P_{i t}, G D P_{i t}, U_{i t}\right)^{\prime} \text {, }
$$


where $M_{i t}$ is the logarithm of the migration rate; $H P_{i t}$ is the logarithm of property prices in region $i$ and in year $t$; $G D P_{i t}$ is the logarithm of GDP per capita; and $U_{i t}$ is the logarithm of the unemployment rate. The second model is the same as the first one except that we add the variable related to social housing supply. This five-dimensional VAR follows:

$$
\text { Model } 2 Y_{i t}=\left(M_{i t}, S H_{i t}, H P_{i t}, G D P_{i t}, U_{i t}\right)^{\prime}
$$

where $S H_{i t}$ is the logarithm of net supply of social housing per capita. It is important to note here that the variables entering into the VAR model are not directly those that we have drawn from the database. First, following Blanchard and Katz (1992), we control for spatial dependence using relative variables, i.e. the regional variables are de-meaned by their national average counterpart for each year. Therefore, the variables in the VAR model represent the percent deviations (log-deviations) from national averages and results below should be interpreted accordingly. Second, we control for individual-specific trends by removing the linear trend in each series.

The choice of the number of lags in the estimated models was made using AIC (Akaike information criterion) and BIC (Bayesian information criterion) tests. This leads us to select one lag. The model thus writes:

$$
Y_{i t}=u_{i}+A Y_{i t-1}+\varepsilon_{i t}, i=1, \ldots, 22 \text { and } t=1990, \ldots, 2013,
$$

where $A$ is the fixed coefficient matrix, $u_{i}$ and $\varepsilon_{i t}$ are the same variables defined in Equation (1).

After having estimated the VAR coefficients, we computed the structural impulse responses using the Choleski decomposition. In this decomposition, series listed earlier in the VAR order can impact the other variables contemporaneously, while series listed later in the VAR order can affect those listed earlier only with a lag. Our choice for the order in which to put the variables is explained below.

First of all, we put the immigration rate before property price. We therefore assume that immigration inflows can contemporary impact property prices, while changing in housing prices can at best impact immigration with a lag. This is because the decision to migrate to France is taken before arrival, and the administrative immigration procedure is quite long (a visa has to be applied for and approved). The procedure is even longer for immigrants coming under family reunification provisions, because the person bringing in his/her family has to apply beforehand for eligibility. It is also very long for those coming to study in France, as they must first apply to a French university. People coming to study or for family reasons account for half of 
all migration flows into France (d'Albis and Boubtane, 2015). Second, we put property prices before GDP per capita due to nominal rigidities, as in Iacoviello (2005) and put GDP per capita before unemployment rate, which is often done in macroeconomic models. Concerning the social housing variable which appears in the second model, we have placed it after migration for the same reason as for property prices. It is placed before property prices in the decomposition because the time lag between the decision to build and the delivery of the building is much longer for social housing than for private homes. This is because the administrative procedure is more cumbersome and the average building size is larger. Of course, we cannot exclude the possibility that immigrants may anticipate the relative economic situations in different regions and that this may affect their choice of one region over another, but we do not think this is a realistic argument, if only because regional economic data are hard to come by. However, we did recalculate our impulse response functions for alternative ordering, and found the results unchanged. $^{5}$

\subsection{Stationarity properties of series}

To choose the appropriate VAR model (VAR in level or in first difference), we first consider the stationarity properties of the series. To this end, we use the second generation panel unit root test developed by Pesaran (2007) that accounts for cross-sectional dependence. This methodology, with the null hypothesis of the presence of a unit root in all series, is based on augmenting the usual augmented Dickey-Fuller (ADF) regression with the lagged cross-sectional mean and its first difference to capture the cross-sectional dependence. Parallel to the t-bar test proposed by Im et al. (2003), the individual $\mathrm{ADF}$ test statistics $(\mathrm{CADF})$ are used to develop the cross-sectionally augmented IPS $\left(C I P S=N^{-1} \sum_{i=1}^{N} C A D F_{i}\right)$, or a truncated version of the CIPS statistic where the individual CADF statistics are suitably truncated to avoid size distortions (particularly in the presence of residual serial correlations and linear trends). Critical values reported in Pesaran (2007) are provided through Monte Carlo simulations and depend on the presence of the deterministic component, and both the cross-sectional and time-series dimensions. The CIPS (CIPS*) test p-value can be computed based on the inverse normal test (or the Z test) suggested by Choi (2001) which combines the p-values of the individual tests $\left(Z=(1 / \sqrt{N}) \sum_{i=1}^{N} \Phi^{-1}\left(p_{i}\right)\right.$, where $p_{i}$ is the p-value for the cross-section unit $i$ ). Simulations made by Pesaran (2007) show that the cross-sectional augmented panel unit root tests have

\footnotetext{
${ }^{5}$ Details are available from the authors on request.
} 
better small-sample power properties. This especially applies to the crosssectionally augmented version of Choi's inverse normal combination test. Therefore, here, we rely on the truncated version of Choi's inverse normal combination test.

Table 2: Panel unit root test

\begin{tabular}{lcc}
\hline \hline Variables & CIPS & P-value \\
\hline Log(real GDP per capita) & $-2.713^{* *}$ & 0.021 \\
Log(unemployment rate) & $-2.277^{* * *}$ & 0.006 \\
Log(migration rate) & $-2.714^{* *}$ & 0.021 \\
Log(housing price) & $-2.734^{* *}$ & 0.016 \\
Log(1+social housing net supply per capita) & $-3.741^{* * *}$ & 0.000
\end{tabular}

Notes: The statistic test is the CIPS truncated version of Pesaran (2007). The test has the null hypothesis of the presence of a unit root. For all series, one lag is introduced to allow for serial correlation in the errors. For the unemployment rate, only the intercept is included, for the other series, intercept and trend are included. ${ }^{* *},{ }^{* * *}$ denote the significance at $5 \%, 1 \%$ levels, respectively.

The results of the panel unit root test of Pesaran (2007) are reported in Table 2. These results show that any series considered does not have a unit root. Particularly, (the logarithms of) real GDP per capita follows a trend stationary process. This finding is in line with those of Carrion-iSilvestre et al. (2005) who have obtained evidence that points to the trendstationarity of GDP per capita in a set of 15 OECD countries (including France) from 1870 to 1994, once cross-sectional dependence and breaks in the series are considered. The result that (the logarithms of) the unemployment rate is mean-stationary supports the natural rate hypothesis in French regions. The migration rate, housing prices and social housing net supply per capita (in logarithms) are characterized by a trend stationary process. The trend-stationarity property of housing prices was also found by Kuethe and Pede (2011) for US state-level quarterly data over the period 1988-2007.

\section{Results}

Since all variables in the system are found to have trend-stationarity, we can set a VAR model taking all the variables considered in levels while controlling for region-specific deterministic trends by removing linear trends in each series. Moreover, as mentioned above, following Blanchard and Katz (1992), we control for spatial dependence using the deviation of each variable from the corresponding national average. 
We will look at the two models in turn. The first model examines the relationship between the immigration rate, property prices, the unemployment rate and GDP per capita, while the second adds social housing supply per capita. Figures 6 and 7 show the impulse response functions (IRFs) obtained from the estimation of the two models, respectively. Shocks are scaled so they represent one unit change in corresponding variable. The $90 \%$ confidence intervals are generated by Monte Carlo with 5,000 repetitions.

Figure 6: Impulse response functions - Model 1
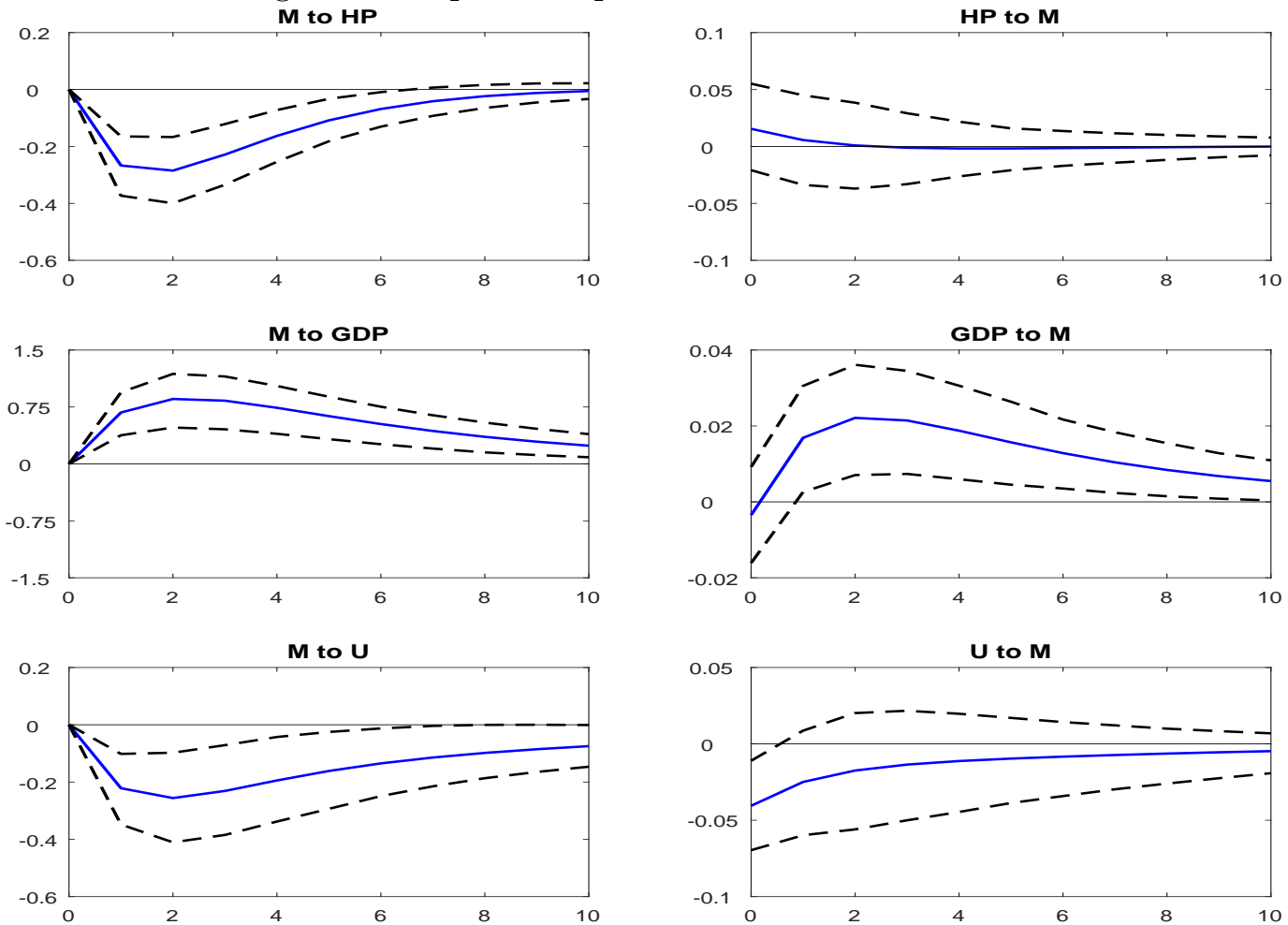

Notes: The variables in the system are, in logarithm, the migration rate $(M)$, real GDP per capita $(G D P)$, the unemployment rate $(U)$ and housing prices $(H P)$. The identification is based on Choleski decomposition with the following ordering $(M, H P, G D P, U)$. Shocks are scaled so they represent one unit change in corresponding variable. The $90 \%$ confidence intervals are generated by Monte Carlo with 5,000 repetitions.

\subsection{Immigration and housing prices}

The relationship between the immigration rate and property prices is particularly interesting. Immigration reacts significantly and negatively to property prices whereas property prices do not react significantly to immigration rates. 
First of all, this finding shows that the positive correlation seen in Figure 5 is not robust when one controls for the two economic variables (GDP per capita and unemployment) and when the endogeneity between the variables is taken into account. This significant relationship is a negative one, and it highlights the lasting effect of property prices on immigration rates. As can be seen from Figure 6, the effect is significant for six years, from the year of the shock to the fifth.

Comparing estimates across studies is problematic due to differences in the countries considered, differences in methodological approaches, the various levels of the data aggregation and the period coverage. That being said, some of our results are in line with those of Akbaria and Aydedea (2012) who found that recent immigrants have no impact on average housing prices in Canada. These authors used panel data based on 258 Census Divisions across Canada for three census years from 1996 to 2006 and estimated the effect of immigration on average housing prices. Moreover, Stillman and Maré (2008) also found no evidence that the inflow of foreign-born immigrants are positively related to regional housing prices in New Zealand. They examined how international migration affects rents and sales prices in different local labour market areas in New Zealand. While the return of the native-born expatriates is associated with the increase of local housing prices, their results do not provide evidence that foreign-born immigrants increased these prices. More recently, employing a VAR approach on Norwegian quarterly data over the period 1990-2014, Furlanetto and Robstad (2016) find that international migration has no impact on housing prices. Furthermore, the influence of housing markets on migration decision was examined by Zabel (2012), who estimated a panel VAR model of 277 US metropolitan areas over the period 1990-2006. He showed that the local housing market is an essential determinant of migration responses to labor demand and supply shocks.

However, our results differ from other studies. In particular, Saiz (2007) found that a $1 \%$ increase in the immigration rate causes a rise in housing values of around 1\% in the United States. He estimated the impact of immigration on rents and house prices using instrumental variables approach on yearly data at the MSA level over the period 1983-1997. He use, as we do, administrative data on immigrant admitted legally to the US but a different methodology. This positive impact of immigration on housing prices can also be found in other studies using the same instrumental variables approach: Degen and Fisher (2009) for Switzerland and Gonzalez and Ortega (2013) for Spain.

It should be noted that some studies using more disaggregated data at the local level (e.g. Saiz and Wachter (2011) for the US and Sá (2015) for 
the UK) find that immigration has a negative effect on housing prices. As for research conducted on France, Sotura (2013) examined the resale property market in Paris between 1993 and 2008. Using an exhaustive database of property transactions over the period, she shows that foreign buyers pay more for their homes than do French buyers but that the effect on prices is negligible. She also highlights the fact that it is primarily foreign buyers living abroad who push prices up, while foreign buyers resident in France have little impact on prices.

The impact of housing prices on immigration can be explained by the particular characteristics of migration into France. There, international migration is mainly for family reasons and immigrants have to meet adequate housing requirements in order to bring their families. As shown in d'Albis and Boubtane (2015), family migration is the largest category of migration, representing more than $50 \%$ of the flows. Immigrants may be spouses of French nationals or families of foreign residents in France arriving under the administrative procedure for family reunification. To be eligible for this procedure a foreign-resident must have a certain level of resources and a home sufficiently large for the family when they arrive. These conditions are probably harder to meet in regions where property prices are high, and this would reduce migration flows into these regions. To test this intuition we estimated a new model, which differentiates between male and female immigrants. The immigration flows of men and of women are considered separately, while the rest of the model is unchanged. In the Choleski decomposition we placed the male migration rate before the female rate because a majority of female immigrants come for family reasons. The impulse response functions we obtained can be seen in Figure A-1 in the Appendix. First, is clear that the main results (significant negative effect of property prices on immigration and non-significant effect of immigration on property prices) are robust. Second, we see that the magnitude of the reactions to a housing price shock differ across genders, the reaction of female migration rate being much larger than the one of male migration rate. This suggests that the housing conditions that immigrants must provide in order to bring their families seem to explain the impact of property prices on immigration rates. Further evidence can be provided by decomposing the flow of immigrants according to their nationality. We have estimated a new model that considers separately the flow of immigrants who are nationals of a high-income country and the flow of those who are national of a developing country. Immigration for family reasons is much more likely in the latter group (Mazuy et al., 2016). Results are reported in Figure A-2 in the Appendix. We immediately see that immigrants from developing countries react to housing prices whereas immigrants from high-income countries barely react to them. 
While the link is hard to establish empirically due to the limitations of the data, the idiosyncrasies of the French housing market could explain at least in part the absence of impact of immigration on housing prices. First, according to OECD estimates, there is no aggregate shortage of housing in France: the stock of housing per inhabitant is, in particular, higher compared to the US (Andrews et al., 2011). Second, France is one of the OECD countries where the housing market reacts least to shocks. This can be explain by several reasons. First, the information on prices is poor, with data on prices usually coming with a delay and only at a rather aggregate level. Second, France's housing market is highly segmented with $76 \%$ of the housing stock as either owner-occupied (58\%) or rented for social purposes (19\%). The social housing sector accounts for $44 \%$ of the French rental market, on average over the period 1990-2013, with significantly lower rents than the private sector. This social housing sector share is 3.3 times higher in France compared to the US (Andrews et al., 2011). On the other hand, the private rental sector is also highly regulated with stringent rent control and stricter tenant-landlord regulations. Finally, compared to the US, transaction costs in France are particularly high, around $14 \%$ of the property value, almost 10 percentage points higher than the US. The segmentation of the market could explain the absence of immigration effect on property prices but, as we shall now show, this does not implies an interaction between social housing and immigration.

\subsection{Social housing}

Figure 7 shows the impulse response functions for the second model, which includes the supply of social housing. These functions give two main results. Firstly, the estimated relationship between immigration, property prices and economic variables are unchanged. In particular, the effect of property prices on immigration rates is still significant for the period running from the year of the shock to the fifth. Secondly, there is no significant relationship between net social housing supply and immigration. In particular, we do not find that a more abundant supply of social housing in a region attracts immigrants to that region.

Two robustness checks can be provided. First, we control for regional heterogeneity. Since Paris is an important region in France with regard to immigrant population (45\%) and social housing (27\%), we exclude it and estimate again Model 2. As shown in Figure 8, our finding remains unchanged. Second, we take into account the fact that household composition may differ across regions. We consider the system described in Model 2 by replacing the variable social housing supply per working-age population by the social housing supply per household. The impulse response functions in Figure 9 show 
Figure 7: Impulse response functions - Model 2
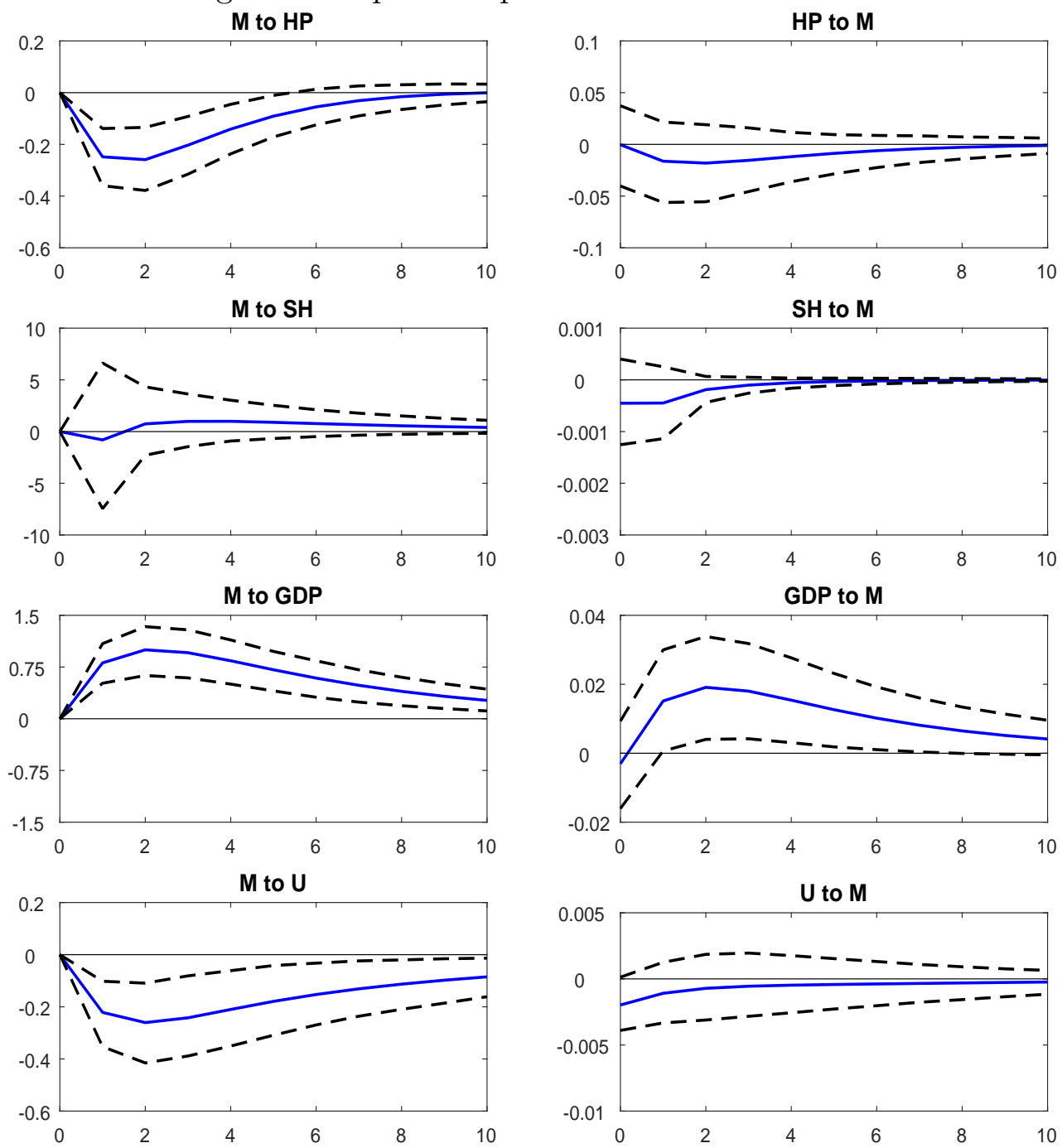

Notes: The variables in the system are, in logarithm, the migration rate $(M)$, real GDP per capita $(G D P)$, the unemployment rate $(U)$, housing prices $(H P)$, and one plus social housing net supply per capita $(S H)$. The identification is based on Choleski decomposition with the following ordering ( $M, S H, H P, G D P, U)$. Shocks are scaled so they represent one unit change in corresponding variable. The $90 \%$ confidence intervals are generated by Monte Carlo with 5,000 repetitions.

that our results are unchanged when we consider this alternative measure of social housing. 
Figure 8: Impulse response functions, without Paris region
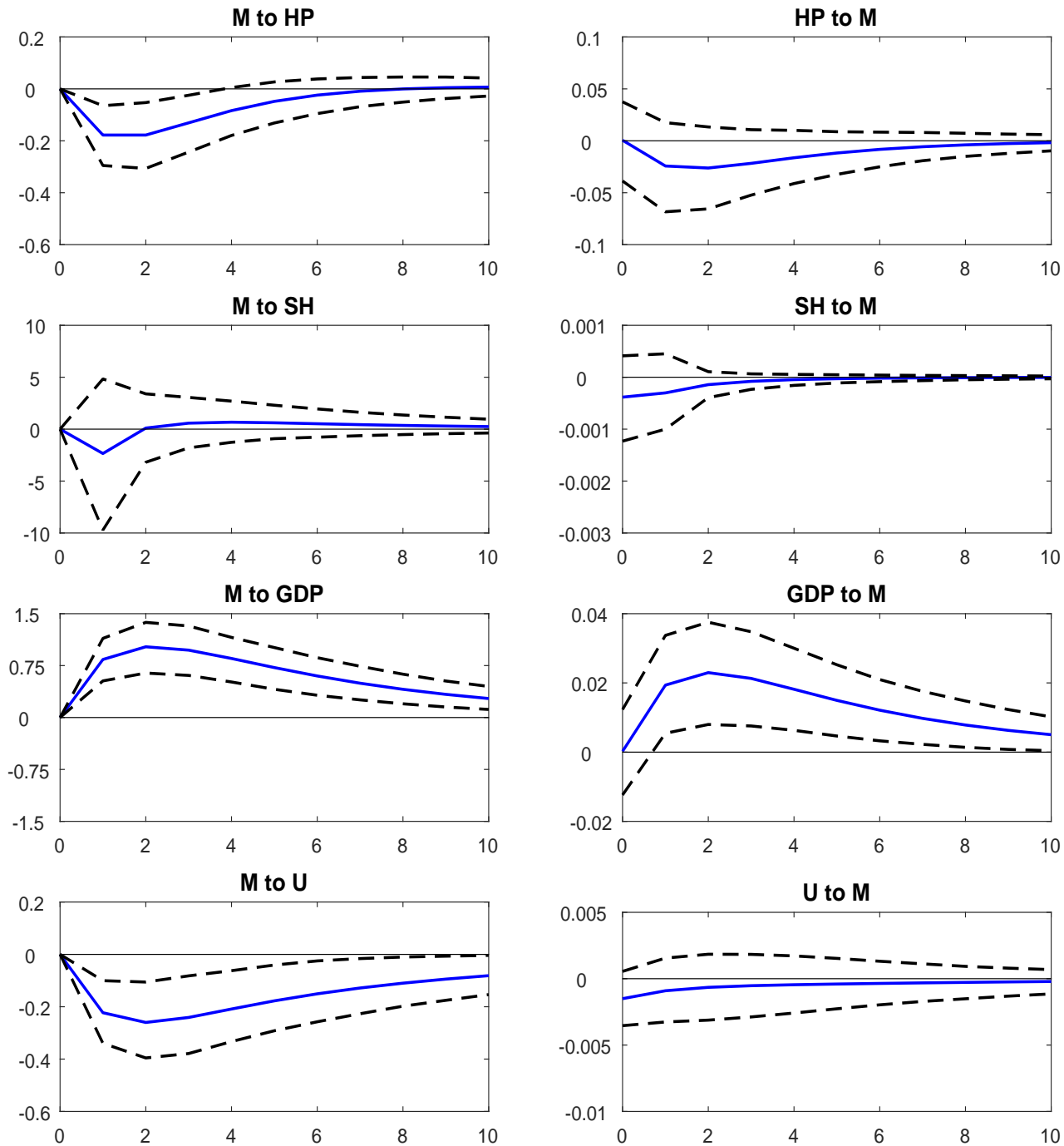

Notes: The variables in the system are, in logarithm, the migration rate $(M)$, real GDP per capita $(G D P)$, the unemployment rate $(U)$, housing prices $(H P)$ and one plus social housing net supply per capita $(S H)$. The identification is based on Choleski decomposition with the following ordering ( $M, S H, H P, G D P, U)$. Shocks are scaled so they represent one unit change in corresponding variable. The $90 \%$ confidence intervals are generated by Monte Carlo with 5,000 repetitions.

\subsection{Regional economic performances}

The impulse response functions reproduced in Figures 6 and 7 also indicate significant response of migration to regional economic performances. Specifically, migration responds positively to GDP per capita and negatively to the 
Figure 9: Impulse response functions, alternative measure of social housing supply
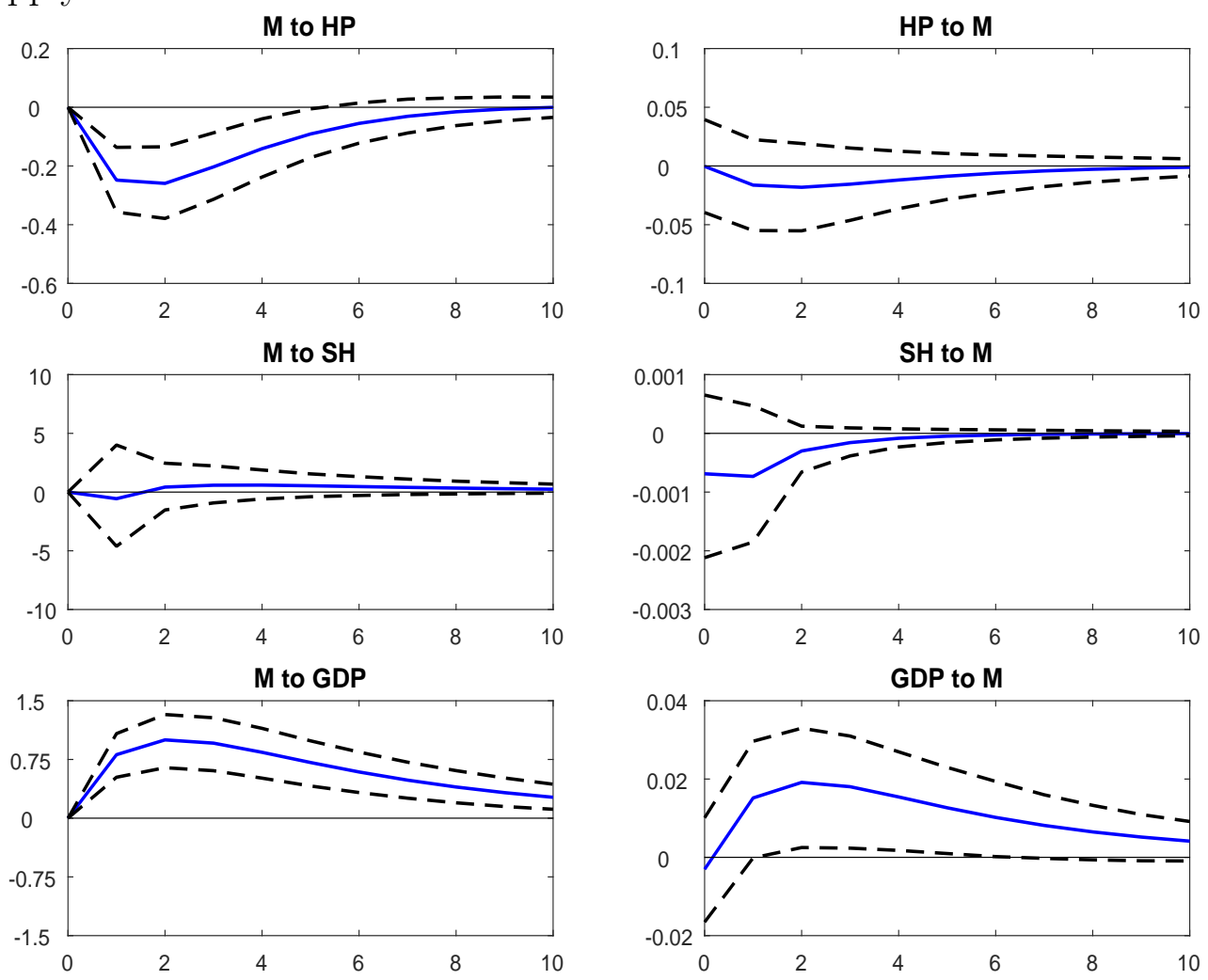

GDP to $M$
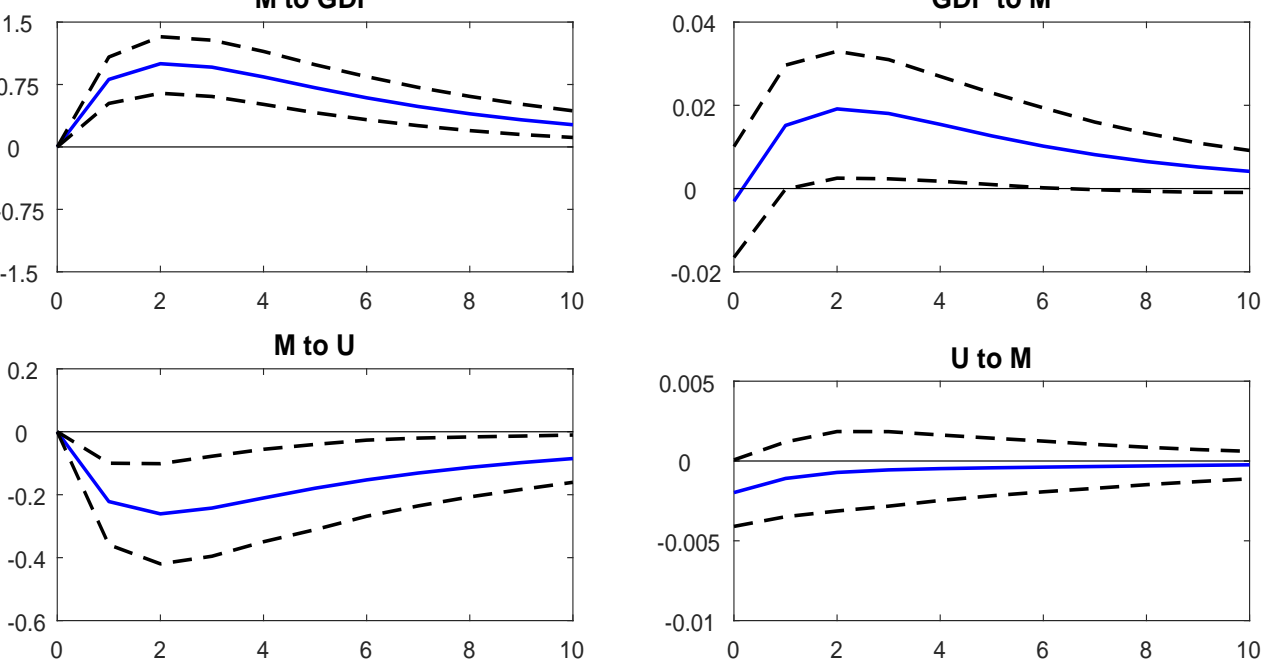

Notes: The variables in the system are, in logarithm, the migration rate $(M)$, real GDP per capita $(G D P)$, the unemployment rate $(U)$, housing prices $(H P)$ and one plus social housing net supply per household $(S H)$. The identification is based on Choleski decomposition with the following ordering ( $M, S H, H P, G D P, U)$. Shocks are scaled so they represent one unit change in corresponding variable. The 90\% confidence intervals are generated by Monte Carlo with 5,000 repetitions.

unemployment rate. The response of the migration rate to GDP per capita is positive and significant for at least 10 years after the shock, whereas the response to unemployment is negative and significant over the same period. 
Conversely, immigration has a positive impact on GDP per capita and no significant impact on the unemployment rate. The positive impact on GDP per capita is significant from one year to six years after the shock.

These results confirm our earlier findings in d'Albis et al. (2016). Estimating a VAR model on monthly data on France (at country level) over the period 1994-2008, we showed that immigration flows significantly respond to France's macroeconomic performance (positively to the country's GDP per capita and negatively to its unemployment rate) and that immigration itself increases France's GDP per capita. These results are thus robust not only to a change in the coverage (regional instead of national), the database (taking into account the date of arrival instead of the date of issue of the residence permit), but also to variables characterizing the housing sector. From this standpoint, France does not seem to differ much from other countries where studies have been conducted with a similar methodology, i.e. in countries with immigration data of sufficiently long-period coverage. Using annual data between 1930 and 2002 at country level for Australia, Canada, and the United States, Morley (2006), found some evidence of long-term causality between immigration and macroeconomic conditions. With Norwegian quarterly data over the period 1990-2014, Furlanetto and Robstad (2016) find that migration has a positive impact on GDP and wages. Moreover, Withers and Pope (1985) for Australia and Islam (2007) for Canada found interactions between migration and unemployment that are similar to ours. On the other hand, for the US, Kiguchi and Mountford (2013) found a temporary negative impact of unanticipated shocks to the labor force while Weiske (2016) found no significant impact of immigration on per capita variables. Employing panel VAR approach on regional data from Spain, from 1999 through 2007, Amuedo-Dorantes and De la Rica (2010) find results indicating that immigration flow reduces regional employment rate disparities only temporarily.

Evidence based on cross-country panel data estimations are mixed, however. Ortega and Peri (2009) estimated a gravity model using data on 14 OECD countries, over the period 1980-2005, and found that immigration had no effect on GDP per capita. Dolado et al. (1994) and Boubtane et al. (2016) estimated an augmented Solow model on cross-country OECD panel data and found that the relative magnitude of the capital dilution with that of the increase in human capital depends on the period of consideration. Our results reinforce the recent studies of Alesina et al. (2016), Ager and Brückner (2013) and Ortega and Peri (2014) who found that immigration promotes total factor productivity by increasing diversity in productive skills. 


\section{Conclusion}

A simple analysis of French regional data over the period 1990-2013 exhibits a positive association between immigration rates of non-Europeans and property prices. In this paper, we estimated a panel VAR model and showed that higher immigration flows do not cause an increase in property prices while higher prices do cause a reduction of immigration flows. Contrary to what would be suggested by descriptive statistics, the relationship is negative. These results differ from some studies conducted for other countries, due to the particular nature of immigration in France, which is mostly motivated by family reasons. Administrative conditions that are necessary to obtain a residence permit for a family notably rely on housing conditions. Those requirements are obviously more difficult to fulfill in regions where housing markets are tense, which consequently reduces immigration. In d'Albis et al. (2016), we showed that family immigration enhanced France's economic performance, as measured by GDP per capita. This suggests that administrative barriers towards family reunification that are linked to housing conditions are counter-productive. Social housing, which amounts to $44 \%$ of rented housing in France, could possibly play a role. We nevertheless showed that our results were not modified when social housing was taken into account. A larger supply of social housing does not affect the impact of property prices on immigration. Moreover, we showed that social housing does not impact location decisions of non-European immigrants. Note that we were not able to discuss the regional implications in France of the freedom of movement of European-citizens, due to data limitations. A potential extension of this work would be to focus on the Paris region, which accounts for $27 \%$ of the country's stock of social housing and $45 \%$ of the country's stock of immigrants. Housing market differences across the Paris region are tremendous and could, therefore, be useful to further understand the relationship between immigration and housing markets. 


\section{Appendix}

Figure A-1: Impulse response functions, by decomposing male and female migration rates
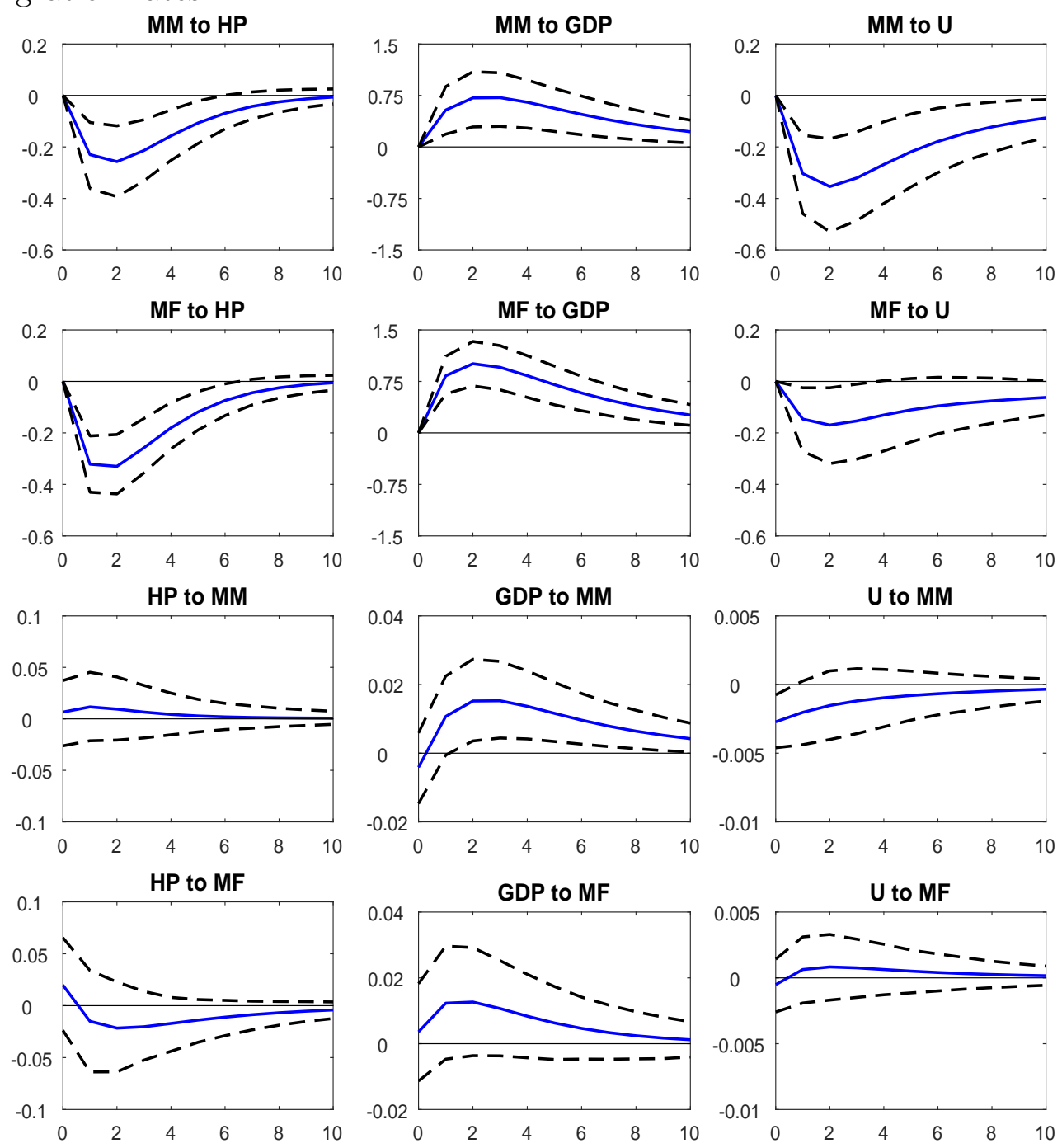

Notes: The variables in the system are, in logarithm, male migration rate $(M M)$, female migration rate $(F M)$, real GDP per capita $(G D P)$, the unemployment rate $(U)$, housing price $(H P)$. The identification is based on Choleski decomposition with the following ordering $(M M, F M, H P, G D P, U)$. Shocks are scaled so they represent one unit change in corresponding variable. The $90 \%$ confidence intervals are generated by Monte Carlo with 5,000 repetitions. 
Figure A-2: Impulse response functions, by decomposing with the immigrants' country of origin
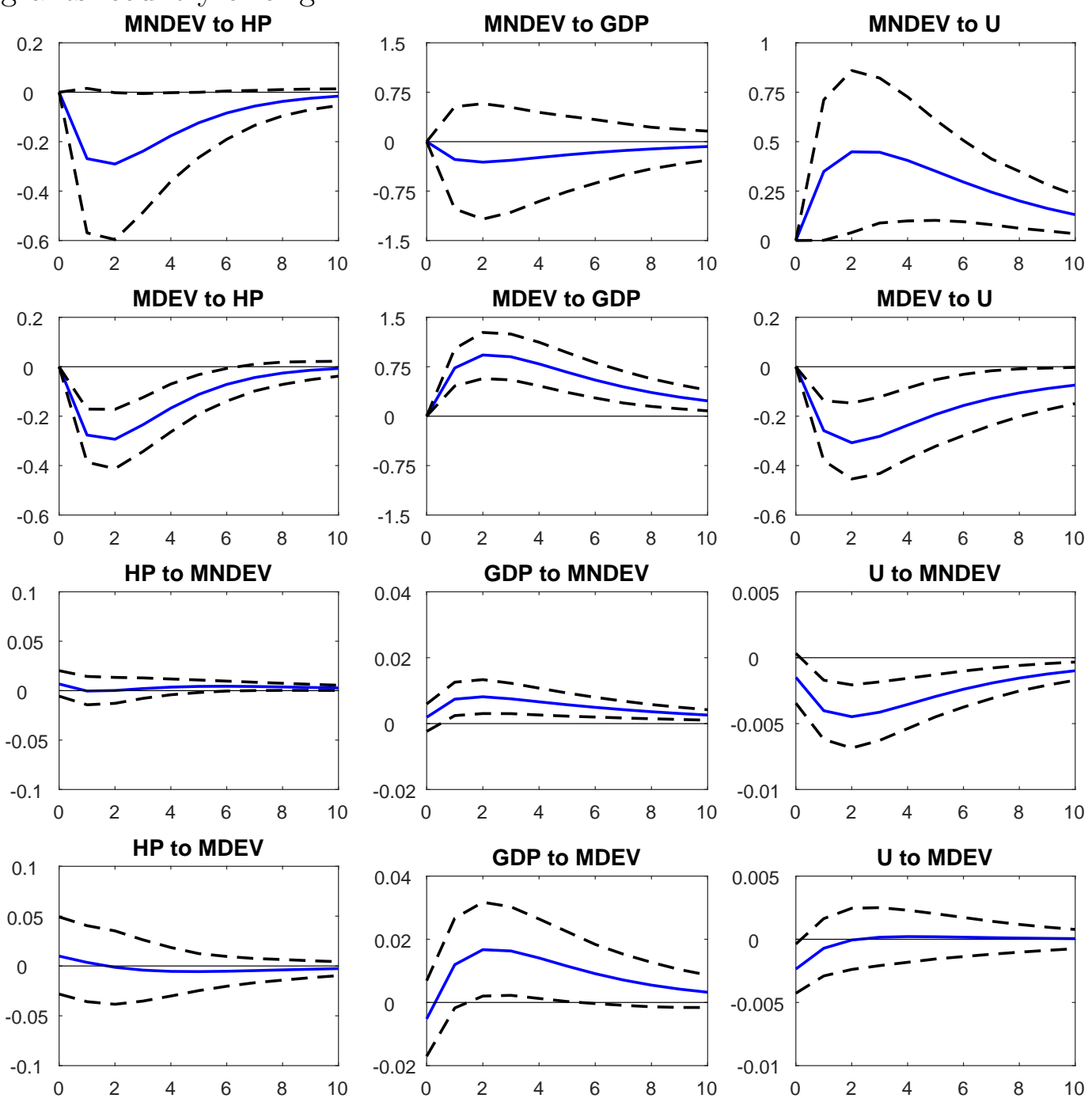

Notes: The variables in the system are, in logarithm, the rate of migration from developing countries $(M D E V)$, the rate of migration from high-income countries $(M N D E V)$, real GDP per capita $(G D P)$, the unemployment rate $(U)$, housing prices $(H P)$. The identification is based on Choleski decomposition with the following ordering $(M N D E V, M D E V, H P, G D P, U)$. Shocks are scaled so they represent one unit change in corresponding variable. The $90 \%$ confidence intervals are generated by Monte Carlo with 5,000 repetitions. 


\section{References}

Ager, P., Brückner, M., 2013. Cultural diversity and economic growth: Evidence from the US during the age of mass migration. European Economic Review 64, 76-97.

Akbaria, A. H., Aydedea, Y., 2012. Effects of immigration on house prices in Canada. Applied Economics 44, 1645-1658.

d'Albis, H., Boubtane, E., 2015. Characteristics of migration flows to France based on residence permit data (1998-2013). Population 70, 461-596.

d'Albis, H., Boubtane, E., Coulibaly, D., 2016. Immigration policy and macroeconomic performances in France. Annals of Economics and Statistics 121-122, 279-308.

Alesina, A., Ardagna, S., Perotti, R., Schiantarelli, F., 2002. Fiscal policy, profits, and investment. American Economic Review 92, 571-589.

Alesina, A., Harnoss, J., Rapoport, H., 2016. Birthplace diversity and economic prosperity. Journal of Economic Growth 21, 101-138.

Amuedo-Dorantes, C., De la Rica, S., 2010. Immigrants' responsiveness to labor market conditions and their impact on regional employment disparities: evidence from Spain. SERIEs 1, 387-407.

Andrews, D., Caldera Sánchez, A., Johansson, A., 2011. Housing markets and structural policies in OECD countries. OECD Economics Department Working Papers 836.

Beetsma, R., Giuliodori, M., Klaassen, F., 2008. The effects of public spending shocks on trade balances and budget deficits in the European Union. Journal of the European Economic Association 6, 414-423.

Blanchard, O. J., Katz, L. F., 1992. Regional evolutions. Brookings Papers on Economic Activity 1, 1-75.

Borjas, G. J., 1999. Immigration and welfare magnets. Journal of Labor Economics 17, 607-637.

Boubtane, E., Coulibaly, D., Rault, C., 2013. Immigration, growth, and unemployment: Panel VAR evidence from OECD countries. Labour: Review of Labour Economics and Industrial Relations 27, 399-420.

Boubtane, E., Dumont, J. C., Rault, C., 2016. Immigration and economic growth in the OECD countries 1986-2006. Oxford Economic Papers 62, 340-360.

Clarenc, P., Côte, J.F., David, A., Frigitt, J., Gallot, P., Gregoir, S., Laferrère, A., Nobre, A., Rougerie, C., Tauzin, N., 2014. Les indices NotairesINSEE de prix des logements anciens. Insee Méthodes 128. 
Carrion-i-Silvestre, J. L., Barrio-Castro, T. D., Lópes-Bazo, E., 2005. Breaking the panels: An application to the GDP per capita. Econometrics Journal 8, 159-175.

Choi, I., 2001. Unit root tests for panel data. Journal of International Money and Finance 20, 249-272.

David, A., Dubujet, F., Gouriéroux, C., Laferrère, A., 2002. Les indices de prix des logements anciens. Insee Méthodes 98.

Degen, K., Fischer, A, 2009. Immigration and Swiss house prices. CEPR Discussion Paper 7583.

Di Pasquale, D., Wheaton, W., 1994. Housing market dynamics and the future of housing prices. Journal of Urban Economics 35,127.

Dolado, J., Goria, A., Ichino, A., 1994. Immigration, human capital and growth in the host country. Evidence from pooled country data. Journal of Population Economics 7, 193-215.

Dustmann, C., Fabbri, F., Preston, I., 2005. The impact of immigration on the British labour market. Economic Journal 115, F324-F341.

Eider database, 2015. Base de données régionales et départementales sur l'environnement, l'énergie, le transport, le logement et la construction. Ministère de l'Environnement, de l'Energie et de la Mer.

Fougère, D., Kramarz, F., Rathelot, R., Safi, M., 2013. Social housing and location choices of immigrants in France. International Journal of Manpower 34, 56-69.

Furlanetto, F., Robstad, Ø, 2016. Immigration and the macroeconomy: Some new empirical evidence. Norges Bank Working Paper 18/2016.

Gonzalez, L., Ortega, F., 2013. Immigration and housing booms: Evidence from Spain. Journal of Regional Science 53, 37-59.

Hahn, J., Kuersteiner, G., 2002. Asymptotically unbiased inference for a dynamic panel model with fixed effects when both $\mathrm{n}$ and $\mathrm{T}$ are large. Econometrica 70, 1639-1657.

Hunt, J., 1992. The Impact of the 1962 repatriates from Algeria on the French labor market. Industrial and Labor Relations Review 45, 556-572

Iacoviello, M., 2005. House prices, borrowing constraints, and monetary policy in the business cycle. American Economic Review 95, 739-764.

Im, K., Pesaran, M., Shin, R., 2003. Testing for unit roots in heterogeneous panels. Journal of Econometrics 115, 53-74.

Islam, A., 2007. Immigration unemployment relationship: The evidence from Canada. Australian Economic Paper 46, 52-66. 
Kiviet, J. F., 1995. On bias, inconsistency, and efficiency of various estimators in dynamic panel data models. Journal of Econometrics 68, 53-78.

Kiguchi, T., Mountford, A., 2013. The macroeconomics of immigration. MPRA Paper No. 45517.

Kuethe, T. H., Pede, V. O., 2011. Regional housing price cycles: A spatiotemporal analysis using US state-level data. Regional Studies 45, 563-574.

Lengyel, B., Eriksson, R.,, 2016. Co-worker networks, labour mobility, and productivity growth in regions. Journal of Economic Geography, forthcoming.

Love, I., Zicchino, L. 2006. Financial development and dynamic investment behavior: Evidence from panel VAR. The Quarterly Review of Economics and Finance 46, 190-210.

Lütkepohl, H., 2005. New introduction to multiple time series analysis. Springer

Mazuy, M., Barbieri, M., Breton, D., d'Albis, H., 2016. Recent Demographic Developments in France: A Decline in Fertility, an Increase in Mortality. Population 71 (3), 395-454

Morley, B., 2006. Causality between economic growth and immigration: An ARDL bounds testing approach. Economics Letters 90, 72-76.

Nickell, S. J., 1981. Biases in dynamic models with fixed effects. Econometrica $49,1417-1426$.

Ortega, F., Peri, G., 2009. The causes and effects of international migrations: Evidence from OECD countries 1980-2005. NBER Working Paper 14833.

Ortega, J., Peri, G., 2014. Openness and income: The roles of trade and migration. Journal of International Economics 92, 231-251.

Pesaran, M. H., 2007. A simple panel unit root test in the presence of crosssection dependence. Journal of Applied Econometrics 27, 265-312.

Sá, F., 2015. Immigration and house prices in the UK. The Economic Journal $125,13931424$.

Saiz, A., 2007. Immigration and housing rents in American cities. Journal of Urban Economics 61, 345-371.

Saiz, A., Wachter, S., 2011. Immigration and the neighborhood. American Economic Journal: Economic Policy 3, 169-188.

Sims, C.A., 1980. Macroeconomics and reality. Econometrica 48, 1-48.

Sotura, A., 2013. Les étrangers font-ils monter les prix de l'immobilier ? Estimation à partir de la base de la chambre des Notaires de Paris, 19932008, Mémoire de Master, Ecole d'économie de Paris, EHESS. 
Stillman, S., Maré, D., 2008. Housing markets and migration: Evidence from New Zealand. Motu Working Paper 08-06.

Verdugo, G., 2016. Public housing magnets: public housing supply and immigrants' location choices. Journal of Economic Geography 16, 237-265.

Weiske, S., 2016. The Macroeconomic effects of postwar immigration to the US. Memo, Goethe University Frankfurt.

Withers, G., Pope, D., 1985. Immigration and unemployment. Economic Record 61, 554-563.

Zabel, J. E., 2012. Migration, housing market, and labor market responses to employment shocks. Journal of Urban Economics 72, 267-284. 